\author{
Elif Kalaycioglu \\ ERAZMUS student, Turkey \\ Professor Dragan Nikodijević, PhD* \\ Faculty of Culture and Media \\ Megatrend University \\ Belgrade
}

\title{
RADIO AND TELEVISION SUPREME COUNCIL: REGULATION ON INTERNET BROADCASTING IN TURKEY
}

\begin{abstract}
The inspection of broadcasting has a vital role in our lives such as protecting children from +18 content and violence as most of the population has access to either regular or online broadcasting. With the development of broadcasting and expanding public to private, there was a need for such an entity. In Turkey, Radio and Television Supreme Council (RTÜK) has made all the audit work of broadcasts. Since it has been established, it has the duty of inspection, regulation, control, and more of television and radio. This council has its own functions inside and its characteristic operational activities. In this essay, starting with the history of broadcasting, RTÜK's description, its duties, management, functions are examined. However, the main topic is how RTÜK has affected online broadcasting with the new regulation and the reactions about this control mechanism.
\end{abstract}

Keywords: Internet, broadcasting, regulation

* Contact: dnikodijevic@megatrend.edu.rs 


\section{Broadcasting in Turkey}

Broadcasting is described in the dictionary as it is the distribution of radio or video content that aims to reach the audience with the mass communication medium. Turkey has started its first broadcasting in 1927 with radio. For long years, it was a monopoly on the hands of government until the beginning of the 1990s. It can be explained Turkey is not very stable between these dates in terms of politics. After that time, the number of private radio broadcasts was increased sharply.

The first television broadcasting was opened in 1952 by the Istanbul Technical University (ITU). This TV broadcast was limited once a week when it started but after specializing on it, the numbers were raised. After, Turkish Radio and Television Corporation (TRT) was established on 1 May 1964 and is started its broadcasting in 1968. In 1971, an agreement about TV broadcasting was signed between ITU and TRT and it was indicated in the agreement that whole TV broadcasting duties were given to TRT. The broadcasting has continued until 1986.

After this date, the second TV channel has opened by TRT. In the process of time, three other channels opened but all these were under the control of either TRT or government. In other words, the first five TV broadcastings were public. The regulations about broadcasting were making difficult to enter this area. That is why TRT was a monopoly in long years. However, these regulations only valid if broadcast working on cable TV. This has created a law deficit which gave birth to open private televisions. They could broadcast on satellite through different countries for this case it was Germany. Moreover, the first private TV in Turkey has started its broadcast in 1990 in the named of Star 1. Star 1 becomes the most-watched channel in Turkey in a short time. Since it was watched more than TRT, the competition arises between two. Later, numerous private and public broadcasting have joined this competition (Özcaglayan,2014). Currently, TRT has six nationwide, six regionals, a local and two international radio channels as well as eleven TV and two international TV channels. (TRT, 2019).

\section{Radio and Television Supreme Council (RTÜK)}

The establishment of a corporation that inspects radio and television broadcast based on 1952 when the first TV broadcast has begun in ITU. It was known as the High Council of Radio and Television (RTYK). Its duty was inspecting TRT and its derivative corporations as at this time there were no other corporations. RTYK has continued its life until 1994. Since RTYK could inspect only public broadcasting, there was a lack of control over private chan-

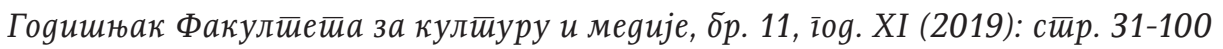


nels which started to be established in 1990. Private televisions have made their broadcast without any restriction for four years. In this time zone, they broadcast was whatever they want even things that unhealthy for children and whenever they want, too. Also, they were not obliged to pay taxes since they are broadcasting based on different countries. These create an absence of law about it and after the realization of the absence of the inspection, the government has begun to search for solutions. In the lights of this information, they conclude RYTK has to be transformed into Radio and Television Supreme Council (RTÜK) under the Law on the Establishment of Radio and Television Enterprises and Their Broadcasts in May 1994. RTÜK was described as an autonomous and neutral institution in there. (Yi it,2019). Moreover, its duty and more are given to RTÜK. Therefore, it can be concluded that "RTÜK was founded out of necessity primarily to regulate radio and television broadcasts and to arrange the distribution and allocation of frequencies within the national boundaries of the country." "Its responsibilities have included setting up rules and regulations for running radio stations and television systems, supervising broadcasting companies, distributing licenses and granting permission for the establishment of private radio and TV stations, monitoring broadcasters, and regulating broadcasting activities." (Kaptan and Karanfil, 2013).

The regulations that were accepted in 1994 have been valid until 2011 even there were changes. After that, authorities have realized that changes corrupt the concept of regulations and with the technological changes in broadcasting, new regulation about RTÜK came into force. This new regulations indicated "The purpose of this Law is to regulate and supervise radio and television broadcasting services and on-demand media services; to ensure the freedom of expression and information; to determine the procedures and principles in relation to the administrative, financial and technical structures and obligations of media service providers and the establishment, organization, duties, competencies, and responsibilities of the Radio and Television Supreme Council." in the jurisdiction of Republic of Turkey (2011).

RTÜK is formed of nine members and these members are representatives of political parties. The number of representatives is chosen according to a member of the political parties by the Turkish Parliament. Every member is chosen for six years and the members elect a President and a Deputy President from among themselves for two years. The board members have to graduate from higher education for at least four years and they have to have work experience in their field at least ten years. The regulation intent to form a board that includes sufficiency on the field and enough experience (Yi it,2019). The Supreme Council meets with a quorum of at least five members and takes decisions with affirmative votes of at least five members and decisions of the Supreme Council are subject to judicial review. (RTÜK, n.d.)

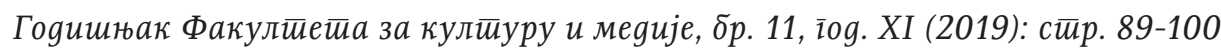




\section{Functions of Supreme Council}

The council has to take precautions in the field of audio-visual media services. These are the main duties of the council. Firstly, it is protected that freedom of expression and information for all the members. Since the members represent a different political opinion, all should express their ideas in a free environment in order to make better decisions. Moreover, diversity of opinion should be protected in the council. Having consensus in the type of these places may bring in take away to reality. Different opinions, ideas, can be assets if it is evaluated accurately. These create the protection of media pluralism in the council. Finally, the council must protect the public interest while doing all the protections. (RTÜK, n.d.)

In order to achieve its goals that mentioned above, "Supreme Council monitors and supervises the broadcasts of media service providers, makes and deploys the television channel and radio frequency planning in the framework of frequency bands for the terrestrial radio and television broadcasts, determines the required administrative, financial and technical standards for a broadcast license; grants broadcast licenses to those of such companies which fulfill the required qualifications; supervises them and revokes the broadcast licenses when required, Performs other functions and uses its powers determined by the Broadcasting Law No: 6112 .

It is indicated in regulation that the supreme council must meet at least once a week. Five members out of nine have to join this meeting. In order to make decisions, all five members must give the same vote and there is no abstaining vote. The meetings are confidential but if there is a need for consulting, people who are expert about the related issue can be invited to the meetings (Yiğit, 2019).

On the annual report of RTÜK (2015), their mission described as "to develop policies, to supervise and regulate the field of audio-visual media services by taking into consideration of the rights, interests, and values of the stakeholders based on freedom of expression and information." Whereas their vision "is to be an internationally recognized regulatory authority which shapes the audio-visual sector." Moreover, quality policy of RTÜK indicated "to maintain the accountability, transparency, respectability of the Council, to encourage new communication technologies, to ensure pluralism in audio-visual media sector on the grounds of ethical principles, to develop awareness among viewers/listeners, to create an audio-visual media environment which guarantees fundamental rights and freedoms and human dignity where freedom of expression and information prevailed."

As public broadcasting, TRT has certain standards and values. As a result, TRT can do its inspection inside of the instruction. On the other hand, the 
content of the broadcast is not the first concern of the private broadcasting channels. Their own inspection branch is weak compere to TRT's. As it is mentioned above, RTÜK was established because of the absence of the inspection in broadcasting.

In today's fast-changing technological world, there are numerous TV and radio channels this makes difficult to inspect all of them. At this point, RTÜK has a different solution to this problem.

Firstly, there is a phone line for complaints comes from citizens. The operations are processed in some steps. After taking the phone call, the institution does pre- examination about it. If the complaint is appropriate for the inspection, they prepare an expert report and council review. Then, they decide whether to apply sanctions or not. In this way, citizens are able to join the inspection process with their consumer awareness. This process is applied without condensing public or private broadcasts for all of them.

Secondly, RTÜK uses a system named Digital Recording Archive and Analysis System (SKAAS). SKAAS digitally archives television and radio channels broadcasting over satellite, cable, terrestrial and the internet, and performs audio and video analysis on recordings. With IP streaming Up to 400 television and 1500 radio broadcasts are watched simultaneously and are analysed. Moreover, broadcasts are recorded in the database indefinitely. Finding scene transitions on video recordings, video clip search, logo recognition, image transcription, and word capture on audio recordings are the other features of SKAAS. With this system, RTÜK can insect broadcast by itself (Ayaydın, 2014).

At the end of the inspection process, the institution makes the decision if the broadcast makes violation, and the answer is yes, the appropriate sanctions are applied according to infringement. First, the corporation which makes violation can take fine. However, the money that comes from that fine does not consider an RTÜK's revenue. The authorities think if this money can be considered as revenue, the number of punishments will increase unfairly. Therefore, fine directly goes to the treasure of the Turkey Republic. Secondly, the corporations can take warning which is the simplest punishment. The warning means if you make this fault again, the bigger punishment comes after. Thirdly, the punishment to stop the broadcast. If RTÜK give this penalty, the channel must broadcast a program instead of the program, that fined, about education, culture, traffic, women's and children's rights, physical and moral development of young people, combating drugs and harmful habits, good use of Turkish language, environmental education, disabled problems, health and similar publicly topics in the same and programs are chosen by the Supreme Council (Ayaydın, 2014). In addition to this, RTÜK can give also temporary broadcast prohibition. In a certain time period like a week, the channels cannot continue its broadcast. Fifthly, RTÜK can cancel the license

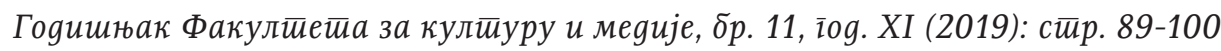


of the broadcasting. However, to make this decision, after the serious violation, RTÜK gives a chance to recover. First, thirty days of shutdown and if the corporation does not recover it the punishment increased by three months and after that, the license is cancelled. Finally, for the more serious violations, RTÜK was able to give the punishment of closing the channel. However, after the last change in the regulation, this rule is not valid anymore.

\section{Online Broadcasting}

For the last two decades, the internet becomes an integral part of our lives. The majority cannot think of a world without the internet. According to the Global Internet Report (2019), 4.388 billion people have internet connection out of 7.676 billion in January.

This means $58 \%$ of the whole world population has internet. Therefore, this contributes to developing online broadcasting. The number of television and radio audiences decreases day by day and people are turning towards online channels. In January $92 \%$ of the internet users watched videos online and $58 \%$ of them steamed TV content via the internet whereas usage of music streaming services was $69 \%$ and $47 \%$ of the users were listening online radio stations. These numbers show that now broadcasting is on the internet. This situation can be explained by giving consumers a lot of choices more than TV and radio services and the accessibility of the contents whenever they want to make the audience choose internet broadcasting over TV and radio.

One of the most used websites online for broadcasting is Netflix. Netflix described itself as "a streaming service that allows our members to watch a wide variety of award- wining TV shows, movies, documentaries, and more on thousand of internet connected devices." It is established in the USA in 1997 as a company that rents DVDs of TV series and films. With the increase of internet usage, it transferred on the online platform. Now it has a subscription system on a monthly base. People are paying 18-42 Turkish liras per month in Turkey, but the prices are changes according to countries. Currently, Netflix has 158.33 million subscribers in the world and over 5.5 million free trial customers (Statista, 2019). Moreover, 1.5 million users are from Turkey. This makes Netflix have a huge market share in Turkey. As an alternative to Netflix, Turkish people are using Puhutv and Blutv. These are online TV platforms that include tv-series and movies. Their contents are totally Turkish, so they only serve in the borders of Turkey. They are working like Netflix mostly; However, Puhutv is free whereas Blutv using a subscription business model. Last numbers show Puhutv has 12 million active users (Puhutv,2019) and Blutv has had 4 million subscribers in 2018. 
The number of users of Netflix, Puhutv, and Blutv have been increasing day by day in Turkey and all have huge market shares here. However, in the 2018 these online media service providers have faced a crisis. Radio and Television Supreme Council has wanted to inspect these channels like $\mathrm{TV}$ and radio. Even this rumor has taken a lot of negative attention from the citizens, the new regulations on the Presentation of Radio, Television and Optional Broadcasts on the Internet were published in the Official Gazette dated 01.08.2019. "Regulation will be applied to online radio, television, ondemand broadcasters, private media service providers and platform operators transmitting such broadcast service" (Aksoy, 2019).

The scope of the regulation includes "(i) the presentation of the broadcast services through the Internet, (ii) the broadcast license to be granted to the media service providers, (iii) the broadcast transmission authority to be granted to the platform operators, and (iv) the supervision of such broadcasts. Article 2 of the Regulation excludes individual communication services from the scope of the Regulation." (Özkan,2019). This means individual broadcast such as YouTube are not embodied by this regulation.

According to Official Gazette "The goal of this regulation is to designate the procedures and principles about the presentation and transmission of the optional broadcasting services through the internet, and to give broadcasting license to the media service providers and broadcasting transmission right to the platform operators, and to inspect the mentioned publishing's."

According to the new regulation, now media service providers have to obtain a broadcast license from RTÜK. However, to obtain this, there must join stock companies in Turkey. The companies that have a center in abroad cannot continue their broadcast online like Netflix. They need to be a company in Turkey. If all qualifications are acquired for the license, there still are several obligations. Media service providers need to keep RTÜK up to date in terms of information and documents provided before, and information on corporate structure. Moreover, they must encrypt both visual and audio content in encrypted broadcasts. They must provide audio and image files used in broadcast services to RTÜK, and this is important because in order to controlled by RTÜK. Providing website addresses, identification tags, addresses, registered emails, and names is also crucial for the process. Finally, they need to pay broadcast license fees which are 10.000 TRY internet radios and 100.000 TRY for television broadcast. The license is granted for ten years. (Özkan,2019).

With the new regulation, there are different opinions either it is necessary, or it caused restriction of freedom. The government is on the side of proinspection. Bekir Bozda who is one of the important people for the AK Party, the ruling party, indicated the necessity of the regulation by saying "Not every regulation is about limiting the freedom of the press and expression, but about 
people who commit other kinds of crimes by making use of it." (BBC,2018). Here Bozda highlighted that this regulation is for the prevent crimes in such platforms. Besides, for Hamit Ersoy, supreme council member, the regulation is necessary to prevent unfair competition and he added: "We have to protect children and the next generation,so we need to handle this problem." (BBC,2018). However, the other side of the coin creates a much more serious problem: blocking freedom of the press and freedom of the citizens. Organization for Security and Cooperation in Europe (OSCE) representative Harlem Désir said if RTÜK has accepted this law, it will be restricted the online broadcasting and the media polyphony. Therefore, this law threats the freedom of the press which was already in danger in Turkey (Euronews, 2018). The left wings in there also think like Désir. CHP and HDP found this regulation censorship on the internet and it was restricting people's freedom. Moreover, the majority of the citizen was especially the users of media service providers disagree with the regulation and they did not want to be accepted. People did not want to be inspected by their preferences and their hobbies in a sense. Although for all the rejections, the regulation was accepted, it is been almost a half year and to conclude it is necessary or not, we need to observe consequences much more.

\section{Conclusion}

In the first half of the century, radio has come into our lives, and in the second half, it has become an irrevocable part of human life until television took its place. The became prevalent of television was in the last decade of the 1900s in Turkey. It took almost 50 years to reach today's version of television when considering the time it was invented. However, as always, there is always another trend to keep up with and, in this case, the Internet came into the scene. The fast-changing world makes the majority of people to use the internet. This brings in the tendency to do most of our activities and jobs online. Broadcasting is also has kept up with changing world and heads for online broadcasting. Now people, are watching their TV and listen to the radio on the internet. Because of this tendency, it becomes hard to control what do people watch. The inspection entities were useless for online until mid-2019 in Turkey. However, with the new regulation, RTÜK has control over online media service providers. For the continue their lives online broadcasters need to take license and follow several rules under this license. But it is very controversial that RTÜK has such control over these. There were two schools of thoughts, one is pre-inspection whereas the other one thing it restricts human freedom. Although even people are still discussing it, the regulation has been accepted and most of the media providers such as Netflix take their licenses and continue its broadcasts. 


\section{References}

[1] Anon, 1970. 4 soruda internete RTÜK denetimi düzenlemesi. BBC News Türkçe. Available at: https://www.bbc.com/turkce/haberler-turkiye-43494950 [Accessed December 28, 2019].

[2] Anon, About. TR. Available at: https://www.rtuk.gov.tr/en/mission-visionquality- policy/5215/5153/mission-vision-and-quality-policy.html [Accessed December 28, 2019].

[3] Aksoy, E., 2019. Turkey: RTUK Is Now Entitled To Supervise Online Media Service Providers. RTUK Is Now Entitled To Supervise Online Media Service Providers - Media, Telecoms, IT, Entertainment - Turkey. Available at: http:// www.mondaq.com/turkey/x/838920/broadcasting film television radio/Podcast IPDC Drug Prices Political Pressures Patents [Accessed December 28, 2019].

[4] Anon, Anasayfa. TRT. Available at: https://www.trt.net.tr/Anasayfa/Anasayfa. aspx [Accessed December 28, 2019].

[5] Ayaydın, D., 2014. RADYO VE TELEVIZYON ÜST KURULU'NUNKAMU YAYINCILIĞI

[6] VE ÖZEL YAYINCILIK ÜZERİNDEKİ YETKİLERİ. Doktora tezi. Ankara Üniversitesi. Ankara.

[7] Euronews \& Euronews, 2018. AGIT: Dijital medyaya RTÜK denetimi basın özgürlüğünü kısıtlar. euronews. Available at: https://tr.euronews. com/2018/02/28/agit-dijital-medyaya- rtuk-denetimi-bas-n-ozgurlugunu-k-stlar [Accessed December 28, 2019].

[8] Anon, 2019. INTERNET BROADCASTS GET RTÜK INSPECTION AS WELL. International

[9] Journalists. Available at: http://www.internationaljournalists.org/ uncategorized/internet- broadcasts-get-rtuk-inspection-as-well.html?lang=en [Accessed December 28, 2019].

[10] Kaptan, Yeşim \& Karanfil, Gökçen, 2013. RTÜK, Broadcasting, and the Middle East: Regulating the Transnational . International Journal of Communication 7.

[11] Anon, National Legislation. TR. Available at: https://www.rtuk.gov.tr/en/ audio-visual-media- law/5350/5139/the-law-no6112-on-the-establishment-ofradio-and-television-enterprises-and- their-media-services-march-3-2011.html [Accessed December 28, 2019].

[12] Anon, Radio and Television Supreme Council. TR. Available at: https://www. rtuk.gov.tr/en/about-rtuk/5297/5083/about-rtuk.html [Accessed December 28, 2019].

[13] Strateji Geliştirme Dairesi Başkanlığı, 2015. Radyo ve Televizyon Üst Kurulu 2015 YILI FAALIYET RAPORU.

[14] Underwood, L., Dubras, R. \& Lore Oxford, 2019. Digital 2019: Global Internet Use Accelerates. We Are Social. Available at: https://wearesocial.com/ 
blog/2019/01/digital-2019- global-internet-use-accelerates [Accessed December 28, 2019].

[15] Watson, A., 2019. Number of Netflix subscribers 2019. Statista. Available at: https://www.statista.com/statistics/250934/quarterly-number-of-netflixstreaming-subscribers- worldwide/ [Accessed December 28, 2019].

[16] Yiğit, Y., 2019. DÜZENLEYİCİ DEVLET VE RADYO, TELEVİZYON PİYASASI

[17] DÜZENLEMESİ: RTÜK ÖRNEĞİ. Yüksek Lisans Tezi. Istanbul Üniversitesi. Istanbul

[18] ÖZÇAĞLAYAN, M. (2014) Türkiye'de Televizyon Yayıncılığının Gelişimi. Selçuk Üniversitesi.

[19] Erişim: http://0search.ebscohost.com.library.metu.edu.tr/login.aspx?direct= true $\&$ AuthType $=\mathrm{ip} \& \mathrm{db}=\mathrm{ir}$ 00559a $\& \mathrm{AN}=$ tuda. article.200911\&site $=$ eds-live (Erişim: 28 Aralık 2019 ).

[20] Özkan, S., Rtuk Regulations On Internet Broadcasts. kavlakavukatlik. Available at: https://www.kavlak.av.tr/rtuk-regulations-on-internet-broadc [Accessed December 28, 2019]. 


\section{Елиф Калајциоглу

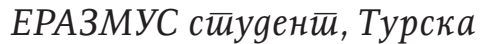

Проф. др Драган Никодијевић

Факулиетеи за кулйуру и меgије

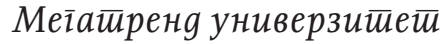

Беоіраg

\section{ВРХОВНИ САВЕТ РАДИЈА И ТЕЛЕВИЗИЈЕ: УРЕДБА О ИНТЕРНЕТ ЕМИТОВАҢУ У ТУРСКОЈ}

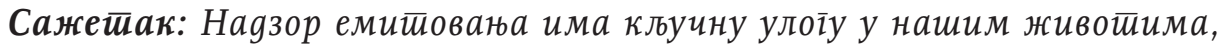

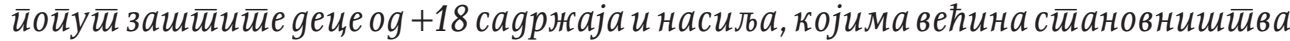
има реgован иристиуй, било кроз редовно или онлајн емитоване. Развојем емитиовања и ширењем јавног у йриватину сферу, јавила се йотиреба за реїулатиорним иетело. У Турској је РТУК (Врховни савети раgија и иеелевизије) извриио наgзор саяржаја који се емитуују, у склаяу са обавезом инсиекиије,

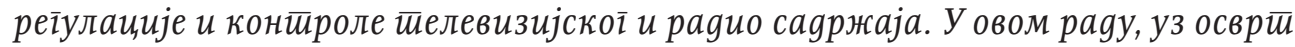

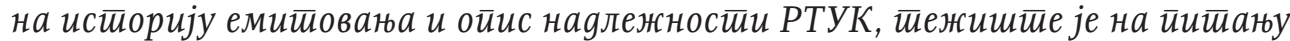
како је новим реіулацијама РТУк уйииао на онлајн емитоване и какве реакиије је изазвао овај нови конитролни механизам. .

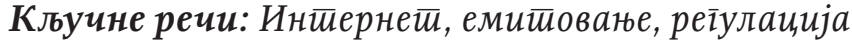

